\title{
UJI AKTIFITAS ANTIPIRETIK EKSTRAK RIMPANG KENCUR (Kaemferia galanga L.) TERHADAP TIKUS PUTIH GALUR WISTAR (Rattus norvegicus)
}

\author{
Yeni Agustin ${ }^{1}$ Maya Wilsya ${ }^{2}$, Muhammad Rizki Tolanda \\ 1,2 Prodi S1 Farmasi STIK Siti Khadijah Palembang \\ Email: yeniagustin03@gmail.com
}

\begin{abstract}
ABSTRAK
Demam dapat didefinisikan dengan suatu keadaan suhu tubuh di atas normal sebagai akibat peningkatan pusat pengatur suhu di hipotalamus, Salah satu tanaman yang banyak digunakan oleh masyarakat Indonesia sebagai obat tradisional adalah kencur. Rimpang kencur mengandung beberapa senyawa aktif. Penelitian ini bertujuan untuk mengetahui efek antipiretik ekstrak rimpang kencur dan mengetahui dosis berapa ekstrak rimpang kencur yang dapat menimbulkan efek pada tikus jantan galur wistar. Sebanyak 24 ekor tikus putih jantan wistar di bagi menjadi 6 kelompok perlakuan: yaitu suspensi ekstrak rimpang kencur dengan variasi dosis $4 \mathrm{mg} / \mathrm{g} \mathrm{BB} ; 5 \mathrm{mg} / \mathrm{g} \mathrm{BB} ; 6 \mathrm{mg} / \mathrm{g} \mathrm{BB} ; 7 \mathrm{mg} / \mathrm{g} \mathrm{BB}$; paracetamol $9 \mathrm{mg} / \mathrm{g} \mathrm{BB}$; dan larutan $\mathrm{CMC}$ 0,5\%). Pengujian terhadap efek antipiretik dilakukan dengan cara mengukur suhu rektal tikus putih jantan wistar dengan interval waktu 30 menit sampai ke 180 menit. Data yang diperoleh di analisis dengan spss ver.20, uji one way ANOVA untuk melihat perbedaan rata-rata setiap kelompok perlakuan. Pada dosis ektrak rimpang kencur $7 \mathrm{mg} / \mathrm{g}$ BB menunjukan tidak adanya perbedaan yang signifikan dengan paracetamol pada menit ke 150 . Hal ini berarti semakin tinggi dosis maka semakin besar efek antipiretik yang akan dihasilkan.
\end{abstract}

Kata Kunci : Ekstrak kencur, efek antipiretik, tikus putih jantan galur wistar.

\begin{abstract}
Fever can be defined by a state of normal body temperature as a result an increase in the temperature control center in the hypothalamus. One of the plants that is widely used by Indonesian people as a traditional medicine is kencur. Kencur rhizome contains several active compounds. The aim of this study was to determine the antipyretic effect of kencur rhizome extract and to find out whether dose of ginger rhizome extract could have an effect on Rattus norvegicus. A total of 24 Rattus norvegicus were divided into 6 treatment groups: the suspension of ginger rhizome extract with a variation of $4 \mathrm{mg} / \mathrm{g} \mathrm{BB} ; 5 \mathrm{mg} / \mathrm{g} \mathrm{BB} ; 6 \mathrm{mg} / \mathrm{g}$ $\mathrm{BB} ; 7 \mathrm{mg} / \mathrm{g} \mathrm{BB}$; paracetamol $9 \mathrm{mg} / \mathrm{g} \mathrm{BB}$; and $0.5 \%$ CMC solution). Tests on antipyretic effects were carried out by measuring the rectal temperature of Rattus norvegicus with intervals of 30 minutes to 180 minutes. The data obtained were analyzed by SSS ver. 20,test one way ANOVA to see the difference in the average of each treatment group. At the extract dose of $7 \mathrm{mg} / \mathrm{g} \mathrm{BB}$, there was no significant difference with paracetamol at 150 minutes. It means that the higher the dose, the greater the antipyretic effect that will be produced.
\end{abstract}

Keywords : Kencur extract, antipyretic effect, Rattus norvegicus. 


\section{PENDAULUAN}

Demam merupakan suatu keadaan suhu tubuh diatas normal sebagai akibat peningkatan pusat pengatur suhu dihipotalamus (Sodikin, 2012). Penyakit penyakit yang ditandai dengan adanya demam dapat menyerang system tubuh. Selain itu demam mungkin berperan dalam meningkatkan perkembangan imunitas spesifik dan nonspesifik dalam membantu pemulihan atau pertahanan terhadap infeksi (Sodikin, 2012).

World Health Organization (WHO) memperkirakan jumlah kasus demam di seluruh Dunia mencapai 16 - 33 juta dengan 500 - 600 ribu kematian tiap tahunnya (Setyowati, 2013).

Salah satu upaya pengobatan demam dapat dilakukan dengan menggunakan tanaman obat tradisional yang berkhasiat. Salah satu tanaman yang banyak digunakan oleh masyarakat Indonesia sebagai obat tradisional adalah kencur. Rimpang kencur mengandung beberapa senyawa aktif. Hasil penelitian Hasanah (2011), Menginformasikan bahwa hasil skrining fitokimia dari rimpang kencur terdeteksi mengandung senyawa kimia golongan flavonoid, polifenol, tanin, kuinolon, dan monoterpen Senyawa metabolit sekunder flavonoid mampu menghambat prostaglandin sehingga mempunyai efek antipiretik (Suwertayasa, 2013).
Antipiretik digunakan untuk membantu untuk mengembalikan suhu set point ke kondisi normal dengan cara menghambat sintesa dan pelepasan prostaglandin E2, yang distimulasi oleh pirogen endogen pada hipotalamus (Sweetman, 2008).

\section{METODE PENELITIAN}

\section{Bahan}

Bahan yang digunakan adalah ekstrak rimpang kencur, paracetamol, vaksin DPT, CMC Na 0,5\%, etanol 96\%, dan aquadest.

\section{Metode Penelitian}

Penelitian ini bersifat eksperimental laboratorium, dan post test control group design. Penelitian ini dilakukan di Laboratorium Farmakologi STIK Siti Khadijah Palembang. Dengan menggunakan hewan uji berupa Tikus Putih Galur Wistar (Rattus norvegicus) jenis kelamin jantan dengan BB antara 100 - 200 gram, dengan keadaan sehat, sebanyak 24 ekor tikus.

\section{Pembuatan Ekstrak Etanol Rimpang Kecur}

Rimpang kencur di ekstraksi dengan metode maserasi, yaitu dengan cara merendam serbuk kering dalam wadah. Rimpang kencur sebanyak $2 \mathrm{Kg}$ di keringkan dibawah sinar matahari dan dilapisi kain hitam, setelah kering di blender 
hingga didapatkan simplisia kering sebanyak 423 gr dan di maserasi menggunakan pelarut etanol 96\% selama 3 hari. Setelah itu di rotary hingga didapatkan ekstrak kental sebanyak 25,9 gr.

\section{Penyiapan Suspensi CMC Na 0,5\%}

Sebanyak 500 mg CMC-Na ditimbang, kemudian dilarutkan dalam sebagian aqua dest hangat, diaduk dan ditambah aqua dest sambil terus diaduk. Setelah larut, sisa aqua dest ditambahkan sampai didapatkan volume larutan CMC-Na $100 \mathrm{ml}$.

\section{Tahap Perlakuan}

Urutan penelitian sebagai berikut :

1. Sebanyak 24 ekor tikus dibagi menjadi 6 kelompok (masing-masing kelompok terdiri dari 4 ekor tikus).

2. Dilakukan pengukuran suhu rektal yaitu dengan cara memasukan termometer digital kurang lebih $2 \mathrm{~cm}$ kedalam rektal tikus untuk mengetahui suhu awal sebelum induksi (suhu standar).

3. Semua tikus diinduksi demam dengan menggunakan vaksin DPT 0,5 ml/ekor secara i.m.

4. 5 jam setelah pemberian penginduksi vaksin DPT dilakuakan kembali pengkuran suhu rekatl tikus.

5. Kemudian tiap kelompok di berikan dosis secara oral sebagai berikut :

a. Kelompok 1 diberi suspensi ekstrak kencur 4 mg/gr BB tikus. b. Kelompok 2 diberi suspensi ekstrak kencur 5 mg/gr BB tikus

c. Kelompok 3 diberi suspensi ekstrak kencur 6 mg/gr BB tikus

d. Kelompok 4 diberi suspensi ekstrak kencur 7 mg/gr BB tikus

e. Kelompok 5 sebagai kontrol positif diberi suspensi paracetamol $9 \mathrm{mg} / \mathrm{gr}$ BB tikus

f. Kelompok 6 sebagai kontrol negatif diberi suspensi $\mathrm{CMC} \mathrm{Na} 0,5 \%$ sebanyak $2 \mathrm{ml}$.

6. Dilakukan pengukuran kembali selama 3 jam dengan interval waktu tiap 30 menit.

7. Hasil data suhu rektal tikus yang diperoleh kemudian dianalisis menggunakan one way Anova.

\section{Hasil dan Pembahasan}

Pengujian efek antipiretik pada penelitian ini menggunakan 6 kelompok perlakuan. Terdiri dari 4 kelompok dengan pemberian ekstrak rimpang kencur (EK) (Kaempferia galanga L.) dengan dosis 4 $\mathrm{mg} / \mathrm{g}$ BB tikus; $5 \mathrm{mg} / \mathrm{g}$ BB tikus; $6 \mathrm{mg} / \mathrm{g}$ BB tikus; 7 mg/g BB tikus; satu kelompok sebagai kontrol positif yang diberikan paracetamol murni, dan Satu kelompok sebagai kontrol negatif yang diberikan CMC-Na 0,5\%. Penggunaan paracetamol sebagai kontrol positif karena berfungsi sebagai kontrol yang memberikan efek dan akan dibandingkan dengan kontrol negatif 
yang tidak memiliki efek. Paracetamol juga merupakan obat yang memberikan efek umum sebagai antipiretik.

Penggunaan vaksin DPT sebagai penginduksi demam karena vaksin DPT terdiri dari difteri, pertusis dan tetanus. Unsur pertusis dalam vaksin yang berasal dari semua sel kuman sering menyebabkan efek samping berupa demam tinggi atau kejang. Bagian pertusis inilah yang berperan sebagai bahan yang meningkatkan terbentuknya sitokin pirogen sepert interleukin-1. Peningkatan interleukin-1 (IL1) menginduksi pembentukan PGE2 di hipotalamus dan menaikkan set point termosat tubuh sehingga menimbulkan demam (Ganong, 2005).

Vaksin DPT diinduksikan melalui i.m sebanyak $0,5 \mathrm{ml} / \mathrm{ekor}$ tikus, setelah 5 jam di induksi suhu rektal tikus meningkat yang artinya terjadi demam. Selisih kenaikan tertinggi yaitu $1,3\left({ }^{\circ} \mathrm{C}\right)$ dan selisih terendah yaitu $0,4\left({ }^{\circ} \mathrm{C}\right)$ dari suhu awal tikus tersebut. Dengan adanya kenaikan suhu tersebut berarti pemberian vaksin DPT dapat menimbulkan keadaan demam.

Hasil pengukuran suhu rektal tikus setiap 30 menit selama 180 menit menunjukan penurunan suhu rektal tikus setelah diinduksi vaksin DPT dan diberikan perlakuan sesuai dengan kelompok masingmasing. Berikut data hasil penelitian.

Tabel1.Hasil pengukuran rerata suhu rektal tikus

\begin{tabular}{ccccccccc}
\hline $\begin{array}{c}\text { Kelomp } \\
\text { ok }\end{array}$ & \multicolumn{7}{c}{ Suhu rektal tikus $\left({ }^{\circ} \mathrm{C}\right)$} \\
\cline { 2 - 9 } & B & B0 & B1 & B2 & B3 & B4 & B5 & B6 \\
\hline I (EK 4 & 37. & 38. & 38. & 38. & 38. & 38. & 38. & 37. \\
mg) & 3 & 0 & 3 & 1 & 4 & 2 & 0 & 9 \\
\hline II (EK 5 & 37. & 38. & 37. & 37. & 37. & 37. & 37. & 37. \\
mg) & 1 & 2 & 9 & 8 & 7 & 5 & 4 & 3 \\
\hline III (EK & 37. & 38. & 37. & 37. & 37. & 37. & 37. & 37. \\
6 mg) & 1 & 1 & 9 & 8 & 7 & 5 & 3 & 3 \\
\hline IV (EK & 37. & 38. & 38. & 37. & 37. & 37. & 37. & 36. \\
7 mg) & 6 & 3 & 1 & 9 & 6 & 3 & 1 & 9 \\
\hline V & 37. & 38. & 38. & 37. & 37. & 37. & 37. & 37. \\
$($ PCT) & 7 & 2 & 0 & 9 & 6 & 4 & 2 & 0 \\
\hline VI & 37. & 38. & 38. & 38. & 38. & 38. & 38. & 38. \\
$($ CMC) & 2 & 1 & 3 & 4 & 6 & 8 & 8 & 8 \\
\hline
\end{tabular}

Tabel 2. Hasil Uji Anova Suhu Rektal Tikus Pengamatan

\begin{tabular}{ccccccccc}
\hline No & \begin{tabular}{c} 
Suhu \\
rektal \\
\cline { 3 - 7 }
\end{tabular} & EK 4 & EK 5 & EK 6 & EK 7 & PCT & CMC & value \\
& tikus ( $\left.{ }^{\circ} \mathbf{C}\right)$ & $\mathrm{mg}$ & $\mathrm{mg}$ & $\mathrm{mg}$ & $\mathrm{mg}$ & & $\mathrm{Na}$ & \\
\hline $\mathbf{1}$ & $30^{\prime}$ & 38,3 & 37,9 & 37,9 & 38,1 & 38,0 & 38,3 & .050 \\
\hline $\mathbf{2}$ & $60^{\prime}$ & 38,1 & 37,8 & 37,8 & 37,9 & 37,9 & 38,4 & .000 \\
\hline $\mathbf{3}$ & $90^{\prime}$ & 38,4 & 37,7 & 37,7 & 37,6 & 37,6 & 38,6 & .000 \\
\hline $\mathbf{4}$ & 120 & 38,2 & 37,5 & 37,5 & 37,3 & 37,4 & 38,8 & .000 \\
\hline $\mathbf{5}$ & 150 & 38,0 & 37,4 & 37,3 & 37,1 & 37,2 & 38,8 & .000 \\
\hline $\mathbf{6}$ & 180 & 37,9 & 37,3 & 37,3 & 36,9 & 37,0 & 38,8 & .000 \\
\hline
\end{tabular}


Berdasarkan tes homogenitas diperoleh data antipiretik terdistribusi normal sehingga data tersebut memenuhi standar homogenitas $(>0,05)$ Hasil uji ANOVA menunjukan terdapat perbedaan bermakna $(\mathrm{p}<0,05)$ sehingga dapat dilakukan uji selanjutnya menggubakan post hoc. Dapat dilihat dari kelompok kontrol positif (paracetamol) dengan kelompok EK 4 mg/g BB tikus, pada menit ke 30 sudah menunjukan adanya perbedaan sampai dengan menit ke 180. Begitu juga pada perbandingan antara kelompok paracetamol dan CMC-Na 0,5\% pada menit ke $30 \mathrm{p}$ (sig) menunjukan angka $>0,05$ yanng artinya tidak ada perbedaan namun pada menit ke 60 sampai menit ke 180 menujukan $\mathrm{p}<0,05$ yang artinya ada perbedaan. Pada kelompok dosis perlakuan EK 5 mg/g BB; EK 6 mg/g BB; EK 6 mg/g BB dibandingkan dengan kontol positif (paracetamol) pada menit ke 30 sampai ke menit 180 menunjukan nilai $\mathrm{p}(\mathrm{sig})>0.05$ yang artinya tidak ada perbedaan antar kelompok perlakuan tersebut, hanya saja pada menit ke 150 dosis $5 \mathrm{mg} / \mathrm{g}$ BB menujukan $\mathrm{p}(\mathrm{sig})<0,05$ yang artinya ada perbedaan.

\section{KESIMPULAN}

Dari hasil penelitian dapat disimpulkan sebagai berikut :

1. Terdapat efek antipiretik dari ekstrak rimpang kencur (Kaemferia galanga
L.) pada tikus putih galur wistar (Rattus norvegicus)setelah diberikan induksi vaksin DPT

2. Hasil dari penelitian ini menunjukan pada dosis $5 \mathrm{mg} / \mathrm{g}$ BB sudah menimbulkan efek antipiretik pada tikus putih galur wistar (Rattus norvegicus)menunjukan laju penurunan sebesar $0,3^{\circ} \mathrm{C}$ pada menit ke 30, sedangkan pada dosis $7 \mathrm{mg} / \mathrm{g}$ BB menujukan laju penurunan sebesar $1,4^{\circ} \mathrm{C}$ pada menit ke-180, merupakan hasil yang lebih besar dibandingkan paracetamol yang menunjukan laju penurunan suhu sebesar $1,2^{\circ} \mathrm{C}$ pada menit ke 180 .

\section{DAFTAR PUSTAKA}

Ganong W.F. 2005. Review of medical physiology. 22nd ed. Singapore : Mc Graw Hill. p. 192-201.

Hasanah, A.N., Nazaruddin, F., Febrina, E., dan Zuhrotun, A. (2011). Analisis Kandungan Minyak Atsiri dan Uji Aktivitas Anti inflamasi Ekstrak Rimpang Kencur (Kaempferia galanga L.). Jurnal Matematika \& Sains. 147-153

Setyowati, Lina, Hubungan Tingkat Pengetahuan Orang Tua Dengan Penanganan Demam Pada Anak 
Balita Di Kampung Bakalan

Kadipiro Banjarsari Surakarta,

Skripsi, STIKES PKU Muhamadiah

Surakarta, 2013,

Sodikin, 2012. Prinsip Perawatan Demam

PadaAnak, Pustaka Belajar, Yogyakarta.

Suwertayasa, IMP., Bodhy, W., Edy, HJ., 2013, Uji Efek Antipiretik Ekstra
Etanol Daun Tembelekan (Lantana camara L.) Pada Tikus Putih Jantan Galur Wistar, Pharmacon, 2(3).

Sweetman, S.,C.,2008, Martindale: The Complete Drug Reference, 36th Ed,The Pharmaceutical Press, London, p.8-10 